\title{
Calorimetric study of the early stages of the nanosilica - tricalcium silicate hydration. Effect of temperature
}

\author{
I.F. Sáez del Bosque ${ }^{a}$, S. Martínez-Ramírez ${ }^{\mathrm{a}, \mathrm{b}}$, M.T. Blanco-Varela ${ }^{\mathrm{a}} \bowtie$ \\ a. Instituto de Ciencias de la Construcción Eduardo Torroja (IETcc-CSIC), (Madrid, Spain) \\ b. Instituto de Estructura de la Materia (IEM-CSIC), (Madrid, Spain) \\ $\triangle$ blancomt@ietcc.csic.es
}

\author{
Received 8 October 2014 \\ Accepted 7 May 2015 \\ Available on line 5 October 2015
}

\begin{abstract}
The pozzolanic reaction of nanosilica in contact with $\mathrm{C}_{3} \mathrm{~S}$ was monitored via isothermal conduction calorimetry. Since that reaction is affected by heat, its variations with curing temperature $(25,40$ and $65{ }^{\circ} \mathrm{C}$ ) were also analysed. The findings showed that while $\mathrm{C}_{3} \mathrm{~S}$ hydration was accelerated by both nSA and higher curing temperature, the former impacted the reaction more intensely. Moreover, the presence of nSA was observed to shorten the acceleration stage during $\mathrm{C}_{3} \mathrm{~S}$ hydration, inducing earlier precipitation of portlandite and earlier C-S-H precipitation and nucleation.
\end{abstract}

KEYWORDS: Calorimetry; Tricalcium silicate; Hydration; Temperature; Nanosilica

Citation/Citar como: Sáez del Bosque, I.F.; Martínez-Ramíreza; S.; Blanco-Varela, M.T. (2015) Calorimetric study of the early stages of the nanosilica - tricalcium silicate hydration. Effect of temperature. Mater. Construcc. 65 [320], e070 http://dx.doi.org/10.3989/mc.2015.06814.

RESUMEN: Estudio calorimétrico de las etapas iniciales de la hidratación del silicato tricálcio- nanosílice. Efecto de la temperatura. El estudio de la reacción puzolánica de la nanosilice en contacto con $\mathrm{C}_{3} \mathrm{~S}$ se siguió por calorimetría de conducción isotérmica. Puesto que la temperatura modifica dicha reacción, también se analizó dicho efecto $\left(25^{\circ} \mathrm{C}, 40^{\circ} \mathrm{C}\right.$ y $\left.65^{\circ} \mathrm{C}\right)$. Los resultados obtenidos mostraron que la adición de $\mathrm{nSA}$ al $\mathrm{C}_{3} \mathrm{~S}$ acelera su hidratación, del mismo modo que cuando se aplica temperatura de curado. Sin embargo, la adición de nSA acelera la hidratación del $\mathrm{C}_{3} \mathrm{~S}$ en mayor medida que la temperatura de curado. Además, la adición de nSA conduce a una reducción del periodo de aceleración durante la hidratación del $\mathrm{C}_{3} \mathrm{~S}$ y por tanto conduce a una temprana precipitación de portlandita y también a una temprana precipitación y nucleación de gel C-S-H.

PALABRAS CLAVE: Calorimetría; Silicato tricálcico; Hidratación; Temperatura; Nanosílice

Copyright: (C) 2015 CSIC. This is an open-access article distributed under the terms of the Creative Commons Attribution-Non Commercial (by-nc) Spain 3.0 License.

\section{INTRODUCTION}

The environmental problems stemming from the $\mathrm{CO}_{2}$ emissions generated during cement manufacture have driven studies on new additions to reduce the proportion of clinker in cement and with it the amount of $\mathrm{CO}_{2}$ released into the atmosphere $(1,2)$. In recent years a good deal of interest has arisen around the application of new materials, especially nanomaterials, as additions. One of the foremost such substances is nanosilica, which in addition to acting as a nano-filler and nucleation site for C-S-H gel formation (3) (intrinsic features of nanomaterials), is a pozzolan that reduces the amount of portlandite generated in silicate hydration and furthers the C-S-H gel formation, thereby enhancing the strength, reducing the porosity and favouring the durability of the end product. 
As an amorphous material with high reactive silica content, $\mathrm{nSA}$, when in contact with the portlandite generated during tricalcium silicate hydration, forms additional C-S-H gel, i.e., other than the gel produced during cement hydration (pozzolanic reaction). The presence of $\mathrm{nSA}$ as an addition in cement pastes has been shown to modify the microstructure of the C-S-H gel formed, which has a longer mean chain length than the gels resulting from silicate hydration only (4). The presence of nanosilica and the formation of additional C-S-H gel have also been shown to be able to lower total cement porosity and refine its pore structure, improving its mechanical properties (5) and reducing the permeability of cementitious matrices (6).

Prior studies have confirmed that nSA particles serve as nucleation sites for seeding C-S-H gel, further accelerating alite hydration (7). Such acceleration raises the total heat released during silicate hydration in cements (7). Inasmuch as the pozzolanic reaction is modified by temperature (8), essentially during the early phase of hydration, the present conduction calorimetric study aimed to determine the effect of temperature on the pozzolanic reaction of $\mathrm{nSA}$, in $\mathrm{C}_{3} \mathrm{~S}+10 \% \mathrm{nSA}$ pastes.

\section{EXPERIMENTAL}

Prior characterisation of the nSA used showed its particles to be very small (20-30 nm), its $\mathrm{N}_{2}$ BETdetermined specific surface to be high $\left(371 \pm 2 \mathrm{~m}^{2} / \mathrm{g}\right)$ and its content to consist primarily of amorphous $\mathrm{SiO}_{2}(\sim 90 \%)(4)$. The tricalcium silicate $\left(\mathrm{C}_{3} \mathrm{~S}\right)$ used was laboratory synthesised by firing calcium carbonate with silica gel. The XRD ${ }^{29} \mathrm{Si}$ MAS NMR and DTA findings showed that it was a triclinic $T_{I}$ polymorph with an $\mathrm{N}_{2}$-BET-determined specific surface of $0.4 \mathrm{~m}^{2} / \mathrm{g}(4)$.

Blends were prepared with $90 \mathrm{wt} \% \mathrm{C}_{3} \mathrm{~S}$ and $10 \mathrm{wt} \%$ nSA and $100 \mathrm{wt}^{\circ} \% \mathrm{C}_{3} \mathrm{~S}$ was used as the control.

Calorimetric readings were taken at three curing temperatures $\left(25,40\right.$ and $\left.65^{\circ} \mathrm{C}\right)$ with a Thermometric TAM Air analyser fitted with eight calorimetric channels having twin chambers, with each channel able to operate separately. The sample was placed in one of the chambers and water (used as a reference in accordance with the literature $(9,10))$ in sufficient amounts to have the same heat capacity as the paste studied in the other. The pastes $\left(\mathrm{C}_{3} \mathrm{~S}\right.$ or $\left.\mathrm{C}_{3} \mathrm{~S}+\mathrm{nSA}\right)$ were mixed with a spatula for 3 minutes outside the calorimeter in ampoules, which were then placed immediately into the chambers where measurements were recorded over a total of 72 hours. The samples containing nSA were dry blended prior to preparing the pastes.

The water/solid ratio (w/s) used to hydrate the $100 \mathrm{wt} \% \mathrm{C}_{3} \mathrm{~S}$ was 0.425 , whereas the ratio for the $90 \mathrm{wt} \% \mathrm{C}_{3} \mathrm{~S}+10 \mathrm{wt} \% \mathrm{nSA}$ blend was raised to 0.7 to accommodate the addition's greater water demand.
The use of admixtures to reduce the amount of water in the nSA-containing pastes was ruled out because they modify hydration kinetics. In this study it was deemed more suitable to use pastes with similar workability and consistency.

The calorimetric curves shown hereunder refer not to the total paste, but are normalised per gram of solid $\left(\mathrm{C}_{3} \mathrm{~S}\right.$ or $\left.\mathrm{C}_{3} \mathrm{~S}+\mathrm{nSA}\right)$.

Acetone was added to both pastes $\left(100 \mathrm{wt} \% \mathrm{C}_{3} \mathrm{~S}\right.$ and $90 \mathrm{wt} \% \mathrm{C}_{3} \mathrm{~S}+10 \mathrm{wt} \% \mathrm{nSA}$ ) at 25,40 and $65^{\circ} \mathrm{C}$ after each heat flow peak and at the age of 24 hours to detain hydration. The pastes were then studied by differential thermal analysis and thermogravimetry (DTA/TGA). The DTA/TGA analyses were conducted on a TA Instruments SATQ600 thermal analyzer (TA instruments, New Castle, DE) in a dynamic nitrogen atmosphere in which the samples were heated at a rate of $4{ }^{\circ} \mathrm{C} / \mathrm{min}$ from the ambient temperature to $1050^{\circ} \mathrm{C}$.

Specific surface was measured on a Micrometrics ASAP 2010, using a flow of $\mathrm{N}_{2}-77 \mathrm{~K}$. The relative adsorption pressure ranged from 0.003 to 0.3 .

\section{RESULTS AND DISCUSSION}

When monitored with isothermal conduction calorimetry (Figure 1), $\mathrm{C}_{3} \mathrm{~S}$ hydration at $25^{\circ} \mathrm{C}$, exhibited five stages: 1) pre-induction or initial dissolution; 2) induction; 3) acceleration; 4) deceleration; 5) diffusion (11).

\section{1) Initial dissolution period}

The first stage of hydration, when in the first few minutes of the reaction calcium and silica pass rapidly into solution, could not be monitored on all the calorimetric curves because the pastes were prepared outside the calorimeter. This stage was

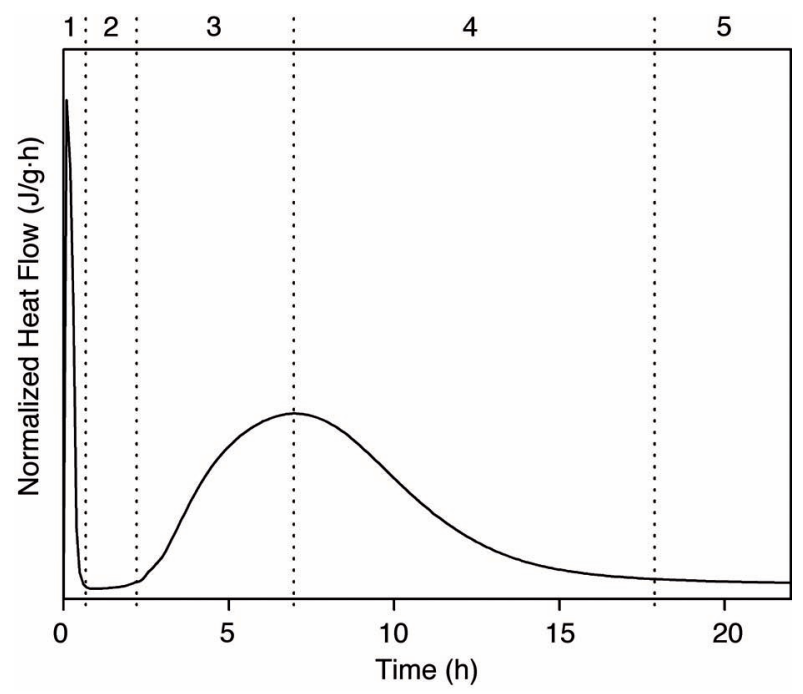

FIgURE 1. Normalised heat flow during triclinic $\mathrm{T}_{\mathrm{I}} \mathrm{C}_{3} \mathrm{~S}$ hydration at $25^{\circ} \mathrm{C}$. 

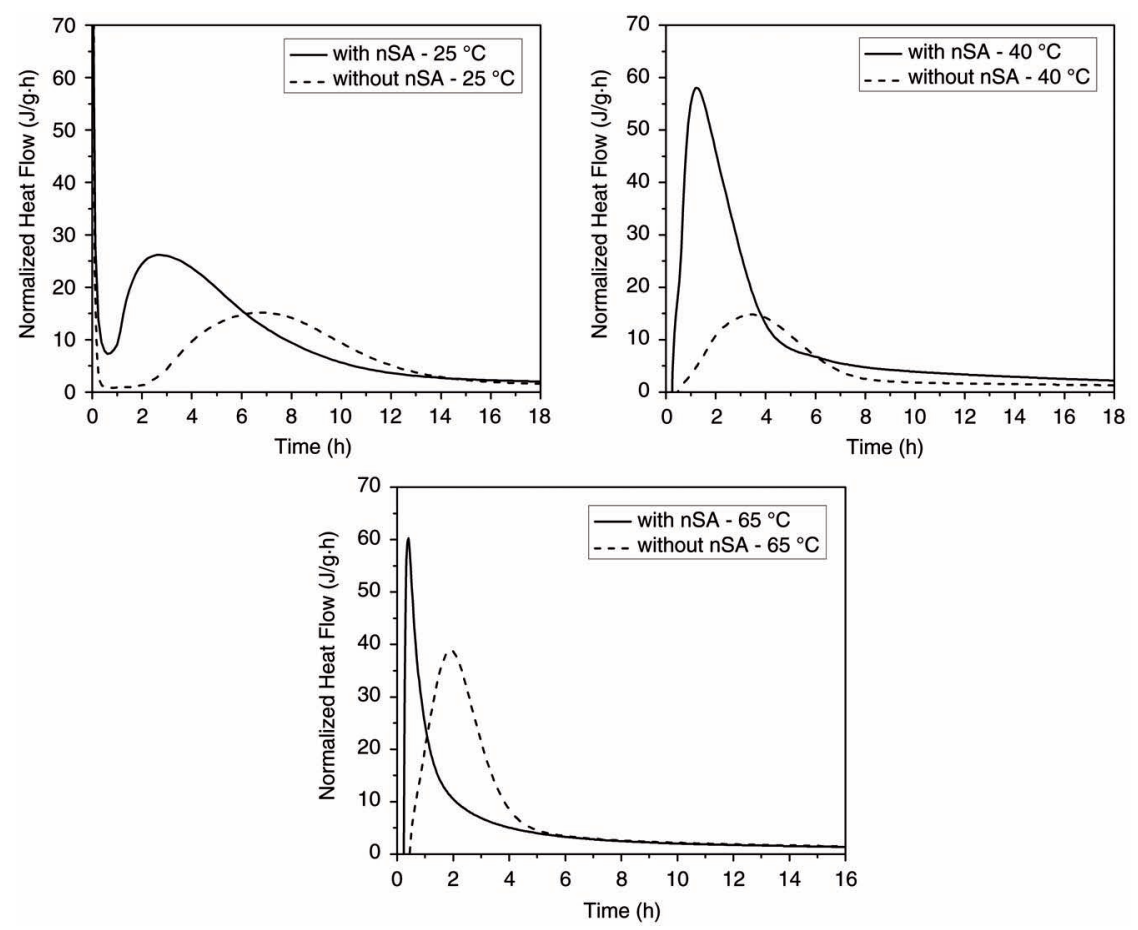

Figure 2. Normalised heat flow curves for $100 \mathrm{wt} \% \mathrm{C}_{3} \mathrm{~S}$ and $90 \mathrm{wt} \% \mathrm{C}_{3} \mathrm{~S}+10 \mathrm{wt} \% \mathrm{nSA}$ hydration at 25,40 and $65^{\circ} \mathrm{C}$.

consequently observed in the $25^{\circ} \mathrm{C}$ samples only and then only partially (Figure 2).

\section{2) Induction period}

In the second or induction stage (likewise only observable in pastes cured at $25^{\circ} \mathrm{C}$ ), the heat flow rate was lower than in the preceding stage. In general, rising temperature has also been reported to shorten the duration of this stage (11).

A number of theories (protective layer, semipermeable layer, C-S-H nucleation and growth rates, $\mathrm{CH}$ nucleation, crystallographic defects) have been put forward to explain the decline in heat flow during the induction stage in alite hydration (11-14). Juilland et al. (14) proposed a mechanism based on geochemical data, noting that during induction period the concentration of $\mathrm{Ca}^{2+}$ and $\mathrm{OH}^{-}$ions rose, with portlandite reaching supersaturation. C-S-H gel precipitation also began in this stage and rapid hydrates growth led to supersaturation of the solution. That induced speedy consumption of the dissolved silicon ions, curbing alite dissolution and bringing the induction stage to an end.

The presence of nSA shortened this second stage, which in the pure $\mathrm{C}_{3} \mathrm{~S}$ pastes ended at 0.79 hours and in the blended pastes at 0.61 hours. Moreover, heat flow during induction was greater in the pastes containing nSA $(7.32 \mathrm{~J} / \mathrm{g} \cdot \mathrm{h})$ than in the unblended materials $(0.82 \mathrm{~J} / \mathrm{g} \cdot \mathrm{h})$. In the latter, the rate of heat released after the dissolution peak remained at around zero, denoting a possible pause in silicate hydration. In the blended pastes, in contrast, the heat released value was one order of magnitude higher. Both the higher heat flow and the shorter induction period suggested an increase in the rate of $\mathrm{C}_{3} \mathrm{~S}$ dissolution and stimulation of C-S-H gel nucleation and growth. The nSA-mediated pozzolanic reaction might prevent the supersaturation of $\mathrm{Ca}^{2+}$ and $\mathrm{OH}^{-}$ions and stimulate the $\mathrm{C}_{3} \mathrm{~S}$ dissolution. Rapid C-S-H gel precipitation and growth would remove the $\mathrm{Ca}^{2+}$ ions from the medium, furthering $\mathrm{C}_{3} \mathrm{~S}$ dissolution and thereby shortening the induction stage. The high specific surface of nSA may be another factor that would shorten induction in the nSA-bearing pastes. Other authors (15) have reported shorter induction stages in $\mathrm{C}_{3} \mathrm{~S}$ hydration with the use of other nanomaterials such as nano- $\mathrm{CaCO}_{3}$. Such findings run counter, however, to the Land et al. (7) observations, according to which the addition of nanosilica to white cement lengthened the induction stage slightly.

\section{3) and 4) acceleration and deceleration periods}

The following two stages of hydration (acceleration and deceleration period) constituted the main exothermal signal on all the heat flow curves for the $\mathrm{C}_{3} \mathrm{~S}$ pastes with and without nSA at the three curing temperatures shown in Figure 2.

During acceleration, the reaction rate depended on uneven C-S-H gel nucleation and growth on the tricalcium silicate and the opportunity for growth on the surface of other phases (16). The reaction rate during deceleration has been believed to be governed 
by diffusion, although other factors, including the consumption of small particles (whereby only larger particles would be available to react) or the lack of space or water, may have also played a significant role $(16,17)$. Recent findings revealed that diffusion does not explain changes in the hydration rate between the acceleration and deceleration stages and that the impingement of different domains of the growing hydration product reduces the surface available for growth. That would readily explain the shift from the accelerating to the decelerating hydration rates (17-20), although diffusion may govern the rate in later stages of deceleration (17).

An analysis of the calorimetric curves for the nSA-free samples revealed that the exothermal peak appeared earlier and heat flow was greater at the higher curing temperatures (Table 1), confirming earlier findings to the effect that temperature accelerated the initial $\mathrm{C}_{3} \mathrm{~S}(4)$ or alite (21) hydration rate.

The steeper slope on the acceleration stage exothermal peak at higher curing temperatures was tantamount to a shorter duration. Since ex-situ preparation precluded visualising the induction stage in the 40 and $65^{\circ} \mathrm{C}$ pastes, that stage may be regarded to have ended at approximately $\mathrm{t}=18 \mathrm{~min}$, the time at which equilibrium was reached between the reference and the experimental sample. The duration of the acceleration stage may therefore be calculated as the difference between the time when the exothermal peak reached its maximum value and the end of the induction stage. Hence, acceleration lasted 5.03, 3.17 and $1.55^{\circ} \mathrm{h}$ at $25^{\circ} \mathrm{C}, 40{ }^{\circ} \mathrm{C}$ and $65^{\circ} \mathrm{C}$, respectively. The peak was, moreover, observed to be narrower at higher temperatures, indicating a shorter deceleration stage, which in this paper was calculated as the difference between the diffusion start time (heat flow between consecutive values lower than $0.01 \mathrm{~J} / \mathrm{g} \cdot \mathrm{h}$ ) and the time when the exothermal peak reached its maximum value. The length of that stage in pastes cured at $25^{\circ} \mathrm{C}$ was $10 \mathrm{~h}$, compared to 5.72 and $5.01 \mathrm{~h}$ in the 40 and $65^{\circ} \mathrm{C}$ pastes, respectively.

Despite the dilution induced by the addition of $\mathrm{nSA}$ ( $2.7 \mathrm{~g}$ of $\mathrm{C}_{3} \mathrm{~S}$ compared to $3 \mathrm{~g}$ in the pure pastes),

TABLE 1. Isothermal conduction calorimetry data for $\mathrm{C}_{3} \mathrm{~S}$ hydrated at $25^{\circ} \mathrm{C}, 40^{\circ} \mathrm{C}$ and $65^{\circ} \mathrm{C}$

\begin{tabular}{lrrr}
\hline & $\mathbf{2 5}^{\circ} \mathbf{C}$ & $\mathbf{4 0}^{\circ} \mathbf{C}$ & $\mathbf{6 5}^{\circ} \mathbf{C}$ \\
\hline Maximum normalised heat flow (J/g.h) & 15.17 & 14.85 & 38.80 \\
Time (h) & 6.84 & 3.47 & 1.85 \\
\hline
\end{tabular}

TABLE 2. Isothermal conduction calorimetry results for $90 \mathrm{wt} \% \mathrm{C}_{3} \mathrm{~S}+10 \mathrm{wt} \% \mathrm{nSA}$ hydration at $25^{\circ} \mathrm{C}, 40^{\circ} \mathrm{C}$ and $65^{\circ} \mathrm{C}$

\begin{tabular}{lccc}
\hline & $\mathbf{2 5}^{\circ} \mathbf{C}$ & $\mathbf{4 0}^{\circ} \mathbf{C}$ & $\mathbf{6 5}^{\circ} \mathbf{C}$ \\
\hline Maximum normalised heat Flow (J/g.h) & 26.2 & 58.1 & 60.32 \\
Time (h) & 2.72 & 1.23 & 0.40 \\
\hline
\end{tabular}

both total heat and the heat flow at the exothermal peak were observed to be greater than in the unblended pastes at all curing temperatures (see Table 2 and the samples cured at $25^{\circ} \mathrm{C}$, Figure 3 ). Some authors contend that the higher the water/ solid ratio in the mix, the longer is the time of appearance of the maximum heat flow peak $(21,22)$. In the present study, however, the peak appeared earlier in the blended $(\mathrm{w} / \mathrm{s}=0.7)$ than in the unblended $(\mathrm{w} / \mathrm{s}=0.45)$ pastes. All the foregoing supports the premise that the nSA-mediated pozzolanic reaction lowered the concentration of $\mathrm{Ca}^{2+}$ ions in the solution according with other pozzolans (23), leading to re-dissolution of $\mathrm{C}_{3} \mathrm{~S}$, accelerating its initial hydration and contributing to greater heat flow. At the same time, nanoparticles such as nSA may act a seed for hydration product crystallisation, thereby heightening cement hydration (24), which would in turn contribute to greater heat flow. Furthermore, the formation of additional C-S-H gel with the pozzolanic reaction could also have contributed to raising the heat flow in the blended pastes. According to a study by Alizadeh et al. (25), the addition of synthetic C-S-H gel (synthesised with stoichiometric amounts of $\mathrm{CaO}$ and $\mathrm{SiO}_{2}$ ) accelerated $\mathrm{C}_{3} \mathrm{~S}$ hydration. That would be similar to the effect that must be caused by the pozzolanic reaction and is consistent with the results reported by Land et al. (7). These authors likewise observed a rise in heat flow when white cement hydration was doped with nanosilica and reported that the higher the specific surface of the $\mathrm{nSA}$, the greater was the amount of heat released. Moreover, this initial acceleration of $\mathrm{C}_{3} \mathrm{~S}$ hydration brought C-S-H gel formation and portlandite precipitation forward.

Figure 4 shows the rate of heat released per gram of tricalcium silicate: note that in the absence of nanosilica, temperatures of $65{ }^{\circ} \mathrm{C}$ were needed to generate any material rise in heat flow. In the presence of $\mathrm{nSA}$, however, such a rise was attained at a

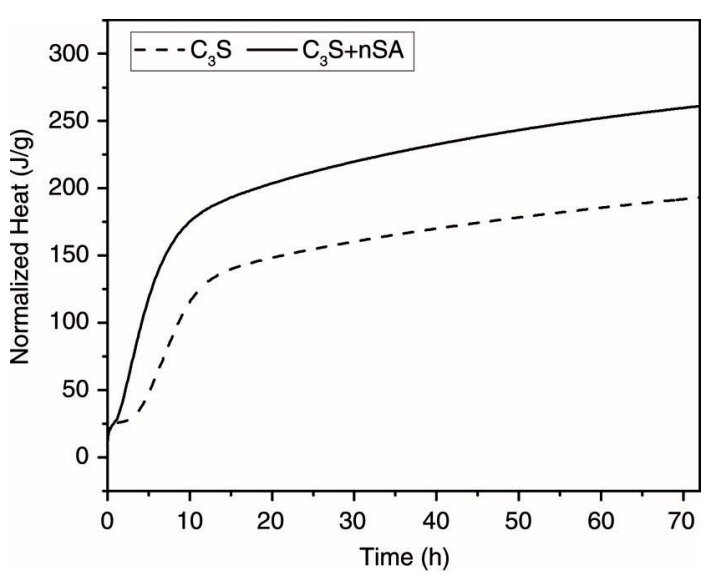

Figure 3. Normalised heat of $\mathrm{C}_{3} \mathrm{~S}$ hydration in $100 \mathrm{wt} \% \mathrm{C}_{3} \mathrm{~S}$ and $90 \mathrm{wt} \% \mathrm{C}_{3} \mathrm{~S}+10 \mathrm{wt} \%$ nSA at $25^{\circ} \mathrm{C}$. 


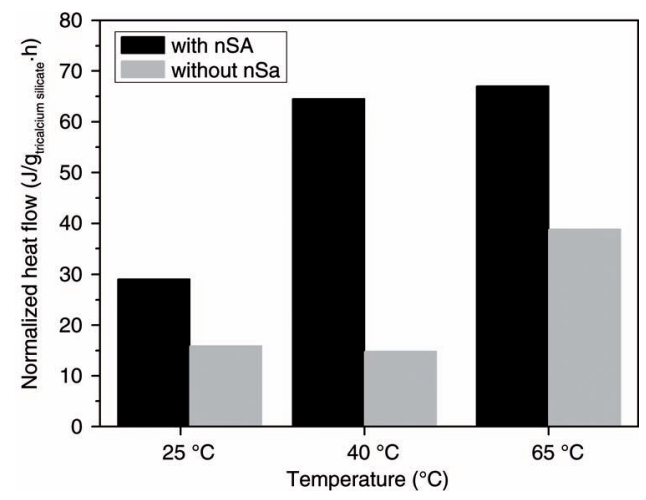

FIGURE 4. Normalised heat flow per gram of $\mathrm{C}_{3} \mathrm{~S}$ during hydration of $100 \mathrm{wt} \% \mathrm{C}_{3} \mathrm{~S}$ and $90 \mathrm{wt} \% \mathrm{C}_{3} \mathrm{~S}+10 \mathrm{wt} \% \mathrm{nSA}$ at 25,40 and $65^{\circ} \mathrm{C}$ (values for maximum heat flow).

lower curing temperature, $40{ }^{\circ} \mathrm{C}$. Even at $25^{\circ} \mathrm{C}$, the addition of nanosilica raised heat flow significantly, while the $65{ }^{\circ} \mathrm{C}$ pastes containing nSA released nearly double the heat recorded for the unblended pastes. Both nanosilica and temperature raised the heat flow rate in initial $\mathrm{C}_{3} \mathrm{~S}$ hydration, although the effect of the addition was more intense.

As in the nSA-free pastes, changes were observed in the exothermal peak on the calorimetric curve for the blended pastes, affecting not only in its slope but also its width, which narrowed at higher curing temperatures due to the shorter duration of the acceleration stage $\left(1.73,0.97\right.$ and $0.1 \mathrm{~h}$ at $25^{\circ} \mathrm{C}, 40{ }^{\circ} \mathrm{C}$ and $65^{\circ} \mathrm{C}$, respectively ). That shorter duration denoted acceleration of $\mathrm{C}_{3} \mathrm{~S}$ hydration in the presence of $\mathrm{nSA}$ due to the pozzolanic reaction, which consumed the portlandite generated during silicate hydration and produced additional C-S-H gel. Further to Thomas et al. (3), the additional C-S-H gel thus formed would seed the formation of more gel from the silicates. However, the length of deceleration stage was compared to the nSA-free pastes, $(13.50,9.27$ and $5.48 \mathrm{~h}$ at 25,40 and $65^{\circ} \mathrm{C}$, respectively).

The calorimetric curves for the pastes studied suggested that nSA pozzolanicity was intense enough to react with portlandite during the acceleration period as well as to hasten $\mathrm{C}_{3} \mathrm{~S}$ hydration. The pastes were hydrated at three test temperatures to verify these two effects. Hydration was detained both at the end of the acceleration period and when the flow of heat released peaked. The pastes obtained were analysed with TG (Figure 5) and FTIR (Figure 6).

The three nSA-free pastes lost mass at 25 to $\approx 390{ }^{\circ} \mathrm{C}$ due to the evaporation of chemically combined water in the C-S-H gel forming. A second phase of mass loss was observed in the $398-453^{\circ} \mathrm{C}$ range, characteristic of the thermal dehydroxylation of portlandite. The rise in intensity of this loss with
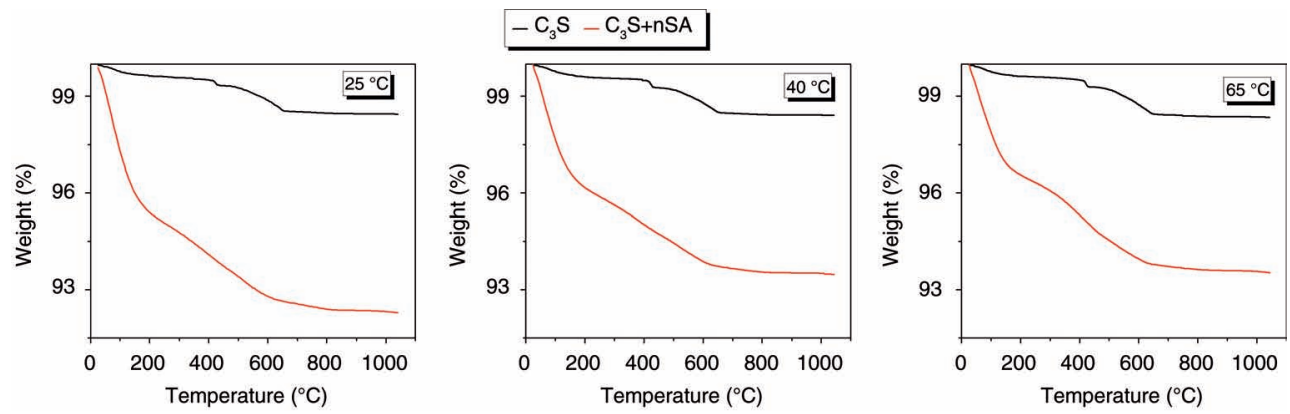

Figure 5. TG analysis of $100 \mathrm{wt} \% \mathrm{C}_{3} \mathrm{~S}$ and $90 \mathrm{wt} \% \mathrm{C}_{3} \mathrm{~S}+10 \mathrm{wt} \% \mathrm{nSA}$ at $25,40 \mathrm{y} 65^{\circ} \mathrm{C}$ (values for maximum heat flow).

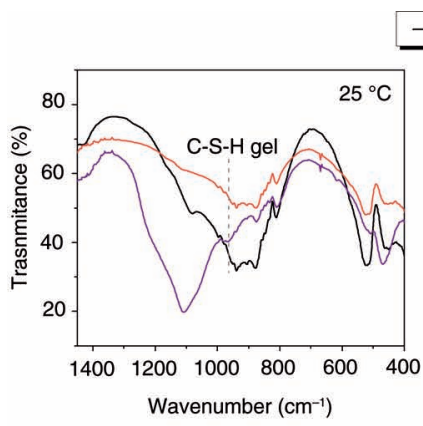

$-\mathrm{C}_{3} \mathrm{~S}$ anhydrous $-\mathrm{C}_{3} \mathrm{~S}+\mathrm{nSA}-\mathrm{C}_{3} \mathrm{~S}$
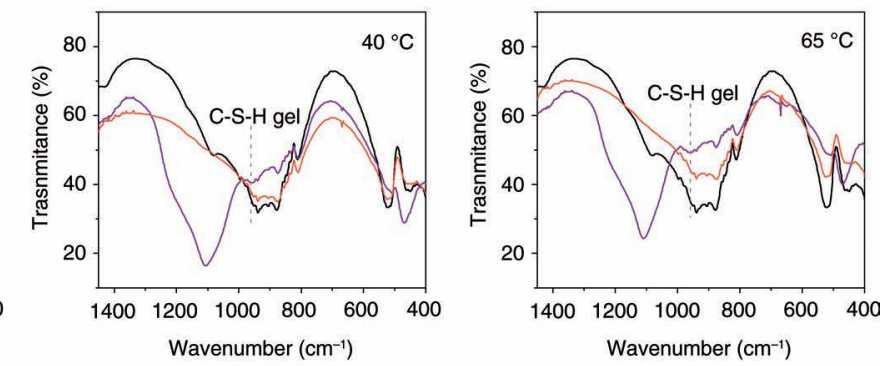

Figure 6. FTIR spectra of anhydrous $\mathrm{C}_{3} \mathrm{~S}$ and hydrated $100 \mathrm{wt} \% \mathrm{C}_{3} \mathrm{~S}$ and $90 \mathrm{wt} \% \mathrm{C}_{3} \mathrm{~S}+10 \mathrm{wt} \% \mathrm{nSA}$ pastes at 25,40 and $65^{\circ} \mathrm{C}$ (values for maximum heat flow). 


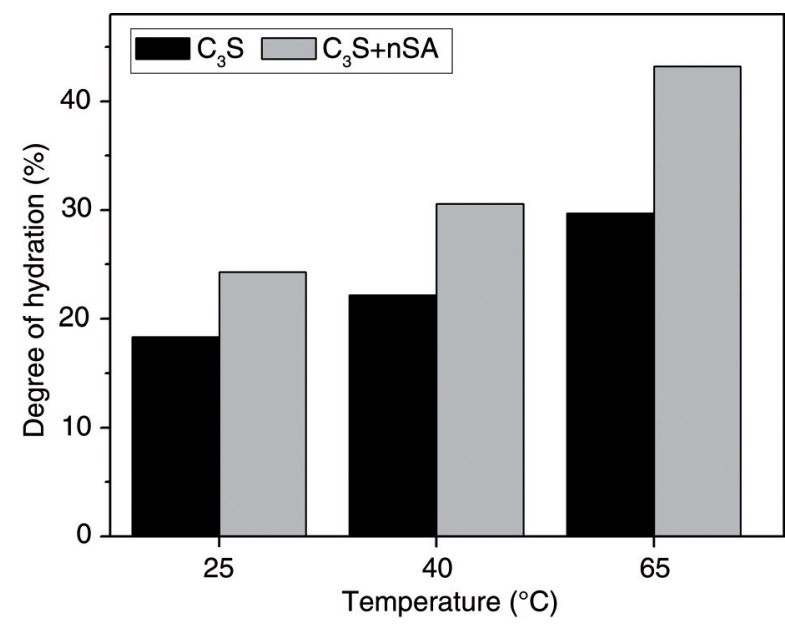

Figure 7. Degree of hydration of $100 \mathrm{wt} \% \mathrm{C}_{3} \mathrm{~S}$ and $90 \mathrm{wt} \%$ $\mathrm{C}_{3} \mathrm{~S}+10 \mathrm{wt} \% \mathrm{nSA}$ at 25,40 and $65^{\circ} \mathrm{C}$ over $24 \mathrm{~h}$.

curing temperature was attributable to the accelerating effect of temperature on $\mathrm{C}_{3} \mathrm{~S}$ hydration. All three samples exhibited mass loss at 453 to $673{ }^{\circ} \mathrm{C}$. Interpreted as a loss of $\mathrm{CO}_{2}$, this was an indication that they were carbonated during handling. The scant total loss recorded (1.5-1.66\%) speaks to the low degree of reaction attained at the test times.

None of the nSA-containing samples exhibited signs of portlandite dehydroxylation, confirming that $\mathrm{nSA}$ reacted with portlandite in the acceleration period of $\mathrm{C}_{3} \mathrm{~S}$ hydration even in the samples hydrated at $25{ }^{\circ} \mathrm{C}$. The total mass loss was much greater in these samples $(6.5-7.52 \%)$ than in the pure $\mathrm{C}_{3} \mathrm{~S}$ pastes, a sign that the $\mathrm{C}_{3} \mathrm{~S}$-water reaction had progressed much farther due to the presence of $\mathrm{nSA}$, despite the shorter times at which hydration was detained.

The FTIR spectra also confirmed that nSA accelerated $\mathrm{C}_{3} \mathrm{~S}$ hydration. All the spectra for the nSA samples contained a C-S-H gel band at around $965 \mathrm{~cm}^{-1}$, attributed, further to Yu et al. (26), to
$\mathrm{Q}^{2}$ units. In the spectra for the samples without the addition the band was much less intense and overlapped with the bands for anhydrous $\mathrm{C}_{3} \mathrm{~S}$. Furthermore, in the nSA-additioned samples, the intensity of the bands characteristic of anhydrous $\mathrm{C}_{3} \mathrm{~S}$ declined with rising curing temperature, denoting greater $\mathrm{C}_{3} \mathrm{~S}$ hydration due to the effect of temperature.

\section{5) diffusion period}

After $24 \mathrm{~h}$, hydration was governed by diffusion in pastes both with and without nSA, which exhibited similar heat flow rates, ranging from 1 to $1.5 \mathrm{~J} / \mathrm{g} \cdot \mathrm{h}$. The ${ }^{29} \mathrm{Si}$ MAS NMR findings on degree of hydration showed that more C-S-H gel formed and the degree of $\mathrm{C}_{3} \mathrm{~S}$ hydration was greater both at higher temperatures and in the presence of nSA (Figure 7) (4). Furthermore, at that age, TG studies revealed differences in the total portlandite $\left(\mathrm{CH}+\mathrm{CaCO}_{3}\right)$ present in the samples. The amount of portlandite, after 24 hours of hydration, rose slightly with higher curing temperatures in the unblended pastes (Figure 8a). In the pastes containing nSA, however, the amount of portlandite rose substantially at $25^{\circ} \mathrm{C}$ as a result of the higher degree of hydration induced in the $\mathrm{C}_{3} \mathrm{~S}$. That effect declined with temperature as a result of the higher intensity of the pozzolanic reaction in the blended pastes. Moreover, in the $24 \mathrm{~h}$ nSA-bearing samples, the amount of water bound to the C-S-H gel (defined as the total mass loss at $1000^{\circ} \mathrm{C}$ less the loss attributed to portlandite dehydroxylation and carbonate decarbonation, Figure 8b) rose substantially, attesting to a speedier water- $\mathrm{C}_{3} \mathrm{~S}$ reaction due to the presence of nSA. In other words, the amount of C-S-H gel was greater in the nSA samples, a finding wholly consistent with the higher degrees of hydration detected with ${ }^{29} \mathrm{Si}$ MAS-NMR.

\section{CONCLUSIONS}

The conclusions that may be drawn around the effect of curing temperature and the addition of nSA on $\mathrm{C}_{3} \mathrm{~S}$ hydration are listed below.
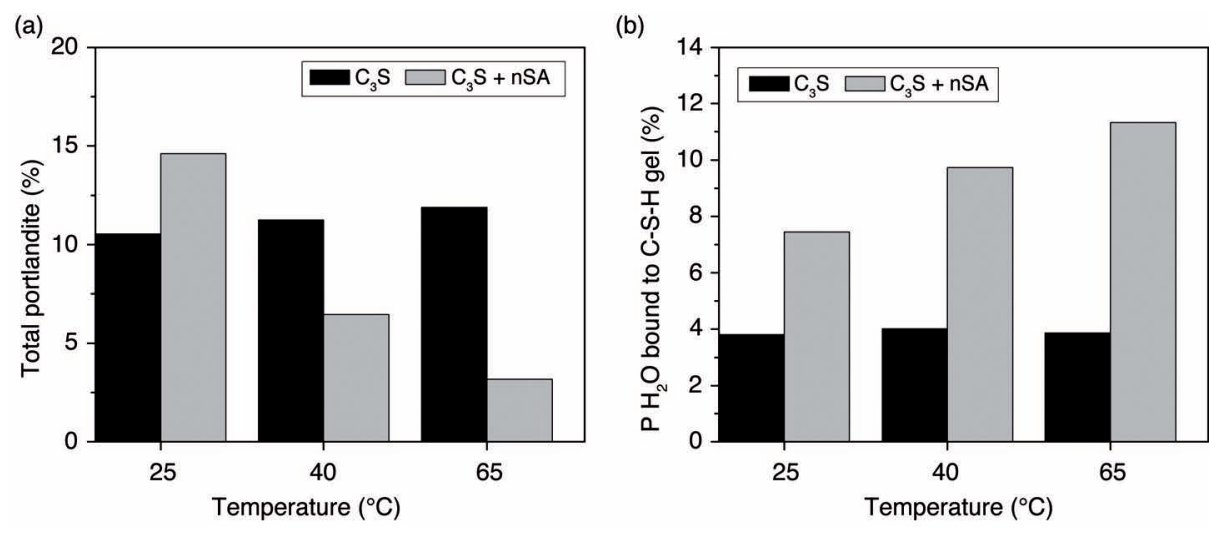

Figure 8. (a) Total portlandite and (b) $\mathrm{H}_{2} \mathrm{O}$ bound to C-S-H generated in 24 hours of hydration of $100 \mathrm{wt} \% \mathrm{C}_{3} \mathrm{~S}$ and $90 \mathrm{wt} \% \mathrm{C}_{3} \mathrm{~S}+10 \mathrm{wt} \% \mathrm{nSA}$ at 25,40 and $65^{\circ} \mathrm{C}$. 
The addition of $\mathrm{nSA}$ accelerates $\mathrm{C}_{3} \mathrm{~S}$ hydration regardless of curing temperature, raising the amount of heat released during hydration. Of course, curing temperature accelerates $\mathrm{C}_{3} \mathrm{~S}$ hydration, generating greater heat flow rates at earlier times, but the accelerating effect of nSA is more intense than the effect of curing temperature, within the limits proposed in the present study.

Adding nSA induces early portlandite precipitation and early C-S-H gel precipitation and nucleation at $25^{\circ} \mathrm{C}$. These factors together with nSA high specific surface reduce induction period.

The addition of nSA also shortens the acceleration stage and lengthen the deceleration stage of $\mathrm{C}_{3} \mathrm{~S}$ hydration at $25^{\circ} \mathrm{C}, 40{ }^{\circ} \mathrm{C}$ and $65^{\circ} \mathrm{C}$.

\section{ACKNOWLEDGEMENTS}

This research was funded by the Spanish Ministry of Education and Science (MAT2006-11705 and CONSOLIDER CSD2007-00058), the Regional Government of Madrid (Geomaterials Programme2, S2013/MIT-2914) and the Spanish National Research Council (PIE: 201160E103). Research fellowship BES-2007-16686 is gratefully acknowledged.

\section{REFERENCES}

1. Lin, L-K.; Wu, W-S.; Lee, H. (2013). Value analysis and properties investigation of high performance rice husk ash concrete. Adv. Mat. Res. http://dx.doi.org/10.4028/www. scientific.net/AMR.773.293.

2. Fairbairn, E.M.R.; Americano, B.B.; Cordeiro, G.C.; Paula, T.P.; Toledo Filho, R.D.; Silvoso, M.M. (2010). Cement replacement by sugar cane bagasse ash: $\mathrm{CO}_{2}$ emissions reduction and potential for carbon credits. J. Environ. Manag. 91, 1864-1871. http://dx.doi.org/10.1016/j.jenvman.2010.04.008.

3. Thomas, J.J.; Jennings, H.M.; Chen, J.J. (2009) Influence of Nucleation Seeding on the Hydration Mechanisms of Tricalcium Silicate and Cement. J. Phys. Chem. C 113, 4327-4334. http://dx.doi.org/10.1021/jp809811w.

4. Sáez del Bosque, I.F.; Martín-Pastor, M.; MartínezRamírez, S.; Blanco-Varela, M.T. (2013) Effect of temperature on $\mathrm{C}_{3} \mathrm{~S}$ and $\mathrm{C}_{3} \mathrm{~S}+$ nanosilica hydration and $\mathrm{C}-\mathrm{S}-\mathrm{H}$ gel structure. J. Am. Ceram. Soc. 96, 957-965. http://dx.doi. org/10.1111/jace. 12093

5. Kontoleontos, F.; Tsakiridis, P.E.; Marinos, A.; Kaoidas, V.; Katsioti, M.(2012) Influence of colloidal nanosilica on ultrafine cement hydration: Physicolchemical and microstructural characterization. Constr. Build. Mater. 35, 347-360. http://dx.doi.org/10.1016/j.conbuildmat.2012.04.022.

6. Ozyildirim, C.; Zegetosky, C. (2010) Exploratory investigation of nanomaterials to improve strength and permeability of concrete. Transport. Res. 2142, 1-2148.

7. Land, G.; Stephan, D. (2012) The influence of nano-silica on the hydration of ordinary Portland cement. J. Mater. Scienc. 47, 1011-1017. http://dx.doi.org/10.1007/s10853-0115881-1.

8. Tashima, M.M.; Soriano, L.; Monzó, J.; Borrachero, M.V.; Akasaki, J.L.; Payá, J. (2014) New method to assess the pozzolanic reactivity of mineral admixtures by means of $\mathrm{pH}$ and electrical conductivity measurements in lime:pozzolan suspensions. Mater. Construcc. 64, e032. http://dx.doi.org/ 10.3989/mc.2014.00914.

9. Wadsö, L. (2010) Operational issues in isothermal calorimetry. Cem. Concr. Res. 40, 1129-1137. http://dx.doi.org/ 10.1016/j.cemconres.2010.03.017.

10. Quennoz, A. (2011) Hydration of $\mathrm{C}_{3}$ A with Calcium Sulfate Alone and in the Presence of Calcium Silicate. Thesis doctoral. EPFL.

11. Barnes, P. (1983). Structure and Performance of Cement. Applied Science Publishers, London, UK.

12. Taylor, H.F.W. (1997) Cement Chemistry. Academia Press, London, U.K.

13. Makar, J.M.; Chan, G.W. (2008) End of the induction period in ordinary portland cement as examined by highresolution scanning electron microscopy. J. Am. Ceram. Soc. 91, 1292-1299.

14. Juilland, P.; Gallucci, E.; Flatt, R.; Scrivener, K. (2010) Dissolution theory applied to the induction period in alite hydration. Cem. Concr. Res. 40, 831-844. http://dx.doi.org/ 10.1016/j.cemconres.2010.01.012.

15. Sato, M.; Diallo, F. (2010) Seeding Effect of Nano- $\mathrm{CaCO}_{3}$ on the hydration of Tricalcium Silicate. Transportation Research Record 2141, 61-67. http://dx.doi.org/10.3141/2141-11.

16. Noor-ul-Amin; Alam, S.; Gaul, S.; Muhammad, K. (2013) Hydration mechanism of tricalcium silicate (alite). Adv. Cem. Res. 25, 60-68. http://dx.doi.org/10.1680/adcr.11.00061.

17. Bullard, J.W.; Jennings, H.M.; Livingston, R.A.; Nonat, A.; Scherer, G.W.; Schweitzer, J.S.; Scrivener, K.L.; Thomash, J.J. (2011) Mechanisms of cement hydration. Cem. Concr. Res. 41, 1208-1223. http://dx.doi.org/10.1016/j.cemconres. 2010.09.011.

18. Thomas, J.J.; Biernacki, J.J.; Bullard, J.W.; Bishnoi, S.; Dolado, J.S.; Scherer, G.W.; Luttge, A. (2011) Modeling and simulation of cement hydration kinetics and microstructure development. Cem. Concr. Res. 41, 1257-1278. http://dx.doi.org/ 10.1016/j.cemconres.2010.10.004.

19. Thomas, J.J. (2007) A New Approach to Modeling the Nucleation and Growth Kinetics of Tricalcium Silicate Hydration. J. Am. Ceram. Soc. 90, 3282-3288. http:// dx.doi.org/10.1111/j.1551-2916.2007.01858.x.

20. Bishnoi, S.; Scrivener, K.L. (2009) $\mu$ ic: A new platform for modelling the hydration of cements. Cem. Concr. Res. 39, 266-274 http://dx doi.org/10.1016/j.cemconres.2008.12.002.

21. Zákoutský, J.; Tydlitát, V.; Cerný, R. (2012) Effect of temperature on the early-stage hydration characteristics of Portland cement: A large-volume calorimetric study. Constr. Build. Mater. 36, 969-976. http://dx.doi.org/10.1016/j.conbuildmat. 2012.06.025

22. Sáez del Bosque, I.F.; Martínez-Ramírez, S.; BlancoVarela, M.T. (2012) From 30 May to 1 June. Influencia de la relación agua/sólido en la hidratación del silicato tricálcico y de dos cementos portland comerciales (Influence of the water/solid ratio on $\mathrm{C}_{3} \mathrm{~S}$ hydration and two portland cement). In XII Congreso Nacional de Materiales IBEROMAT XII. Alicante, Spain.

23. Hewlett, P.C. (1988). Lea's Chemistry of Cement and Concrete. Elsevier, Oxford, U.K.

24. Nazari, A.; Riahi, S. (2011) The effects of $\mathrm{Cr}_{2} \mathrm{O}_{3}$ nanoparticles on strength assessments and water permeability of concrete in different curing media. Mater. Sci. Eng. A 528, 1173-1182. http://dx.doi.org/10.1016/j.msea.2010.09.099.

25. Alizadeh, R.; Raki, L.; Makar, J.M.; Beaudoin, J.J.; Moudrakovski, I. (2009) Hydration of tricalcium silicate in the presence of synthetic calcium-silicate-hydrate. J. Mater. Chem. 19, 7937-7946. http://dx.doi.org/10.1039/B910216G.

26. Yu, P.; Kirkpatrick, R.J.; Poe, B.; McMillan, P.F.; Cong, X. (1999) Structure of calcium silicate hydrate (C-S-H): Near-, Mid-, and Far-Infrared Spectroscopy. J. Am. Ceram. Soc. 82, 742-748. http://dx.doi.org/10.1111/j.1151-2916.1999. tb01826.x. 